\title{
Editorial
}

Cerebrovascular Diseases
Cerebrovasc Dis 2015;40:I-II

DOI: $10.1159 / 000433569$

Published online: May 29, 2015

\section{Is There a New Era for Stroke Therapy?}

At the 2015 European Stroke Conference, the attendees were presented with the positive results of the ESCAPE [1], EXTEND-IA [2], REVASCAT [3] and SWIFT PRIME [4] trials, which have been based on the previously completed MR CLEAN [5] phase 3 clinical trial. The MR CLEAN trial compared the effect of intraarterial treatment (intra-arterial thrombolysis, mechanical treatment or both) with no intra-arterial treatment (best medical management according to national and international guidelines with or without intravenous (IV) thrombolysis) in patients with acute ischemic stroke due to proximal intracranial internal carotid artery (ICA) or middle cerebral artery occlusion with or without extracranial ICA occlusion.

After a series of negative trials reported at recent meetings, these presentations marked a dramatic shift in the perception of mechanical thrombectomy after IV recombinant tissue plasminogen activator (tPA) administration for the treatment of proximal anterior vessel occlusion in patients who were carefully selected according to neuroimaging criteria and exhibited moderate stroke scores. The start of intervention was between 3 and $5 \mathrm{~h}$ after stroke onset in each study. Surprisingly, the publication of the MR CLEAN trial, which was conducted and terminated according to the pre-specified trial protocol including the intention-to-treat and subgroup analyses, prompted the data and safety monitoring boards of the other ongoing endovascular trials to stop and review their own data ahead of time.

Based on the positive findings, several investigators of the discontinued trials have proposed in recent editorials and in a systematic review [6] that the intervention employed in these studies should now be considered the new standard of care for acute stroke patients. Without doubt, these trials will not only serve as a foundation for intense discussions centered on the question of whether highly selected patients may benefit from endovascular reperfusion therapies in addition to standard care, but also serve as a blueprint for a general discussion about the best available and economically affordable management aspects of comprehensive versus standard stroke treatment.

These discussions also have to explain the obvious discrepancy between earlier negative or neutral trials and the recent positive ones. Based on available information, 3 primary reasons are likely to explain the better outcome in the new trials. First, all treated subjects had documented large artery occlusion. Second, the new stent retriever technology was superior to previously used devices, which resulted in higher rates of reperfusion (although full recanalization rates were still somewhat less than expected). Third, due to better patient management, the time between arrival at the hospital and the deployment of endovascular therapy was shorter. However, there are a number of additional questions that have to be answered before changes in guidelines and general recommendations can be reasonably proposed. They are

(1) What is the extent of neurological deficit in terms of the National Institutes of Health Stroke Scale that qualifies patients for bridging treatment and may therefore be used for emergency management and selections of stroke centers that offer endovascular treatment 24/7?

(2) What should be the imaging selection of choice? The present trials used different imaging techniques, mostly CT rather than MRI, and employed different thresholds. For example, the ratio of ischemic tissue at risk to irreversibly infarcted brain was $20 \%$ in the EXTEND- 
IA [2] trial and $80 \%$ in the SWIFT PRIME [4] trial. Similarly, parameters of vascular studies varied considerably, and detailed analysis is necessary to determine whether the amount of contrast media and X-ray irradiation employed is associated with increased risk to the patients.

(3) How should patients who present with acute stroke be treated in the presence of established and well-compensated asymptomatic (or oligosymptomatic) extra- or intracranial occlusions?

(4) How do we deal with occlusions of the posterior circulation, which are particularly difficult to identify in the acute phase without MRI?

(5) How do we treat all those patients who do not fall within the careful clinical and neuroimaging selection criteria of these trials?

(6) How many of our patients are pre-morbid with mRS between 0 and 1 ?

Obviously, these encouraging new data are of great importance to stroke patients and those who care for them. The impressive results and the surrounding excitement might shift the acute stroke treatment consensus into a more aggressive direction. Whether such a change will be of benefit for the majority or even a minority of patients is difficult to predict, but we should keep in mind that these new results were generated in a highly selected group of patients and that the vast majority of these patients were administered a full dosage of alteplase prior to intervention (only REVASCAT [3] requested documentation of a persistent arterial occlusion 30 min after IV tPA administration prior to intervention). Therefore, these data should not be considered definitive for the broad spectrum of acute ischemic stroke. We need careful discussions and additional, fully completed trials that corroborate the interim analyses reported so far by ESCAPE [1], EXTEND-IA [2] and SWIFT PRIME [4].

To continue the discussions of the European Stroke Conference in Vienna, we hereby invite our readers to communicate their opinion and suggestions in the expedited online publication forum of Cerebrovascular Diseases EXTRA during the next few months. Letters or Stroke Notes should be submitted to www.karger.com/ ced_guidelines with the remark 'ESC Discussion Forum' for publication in the journal.

Michael G. Hennerici

\section{References}

1 Goyal M, Demchuk AM, Menon BK, Eesa M, Rempel JL, Thornton J, Roy D, Jovin TG, Willinsky RA, Sapkota BL, Dowlatshahi D, Frei DF, Kamal NR, Montanera WJ, Poppe AY, Ryckborst KJ, Silver FL, Shuaib A, Tampieri D, Williams D, Bang OY, Baxter BW, Burns PA, Choe H, Heo J-H, Holmstedt CA, Jankowitz B, Kelly M, Linares G, Mandzia JL, Shankar J, Sohn S-I, Swartz RH, Barber PA, Coutts SB, Smith EE, Morrish WF, Weill A, Subramaniam S, Mitha AP, Wong JH, Lowerison MW, Sajobi TT, Hill MD; ESCAPE Trial Investigators: Randomized assessment of rapid endovascular treatment of ischemic stroke. N Engl J Med 2015;372: 1019-1030.

2 Campbell BC, Mitchell PJ, Kleinig TJ, Dewey HM, Churilov L, Yassi N, Yan B, Dowling RJ, Parsons MW, Oxley TJ, Wu TY, Brooks M, Simpson MA, Miteff F, Levi CR, Krause M, Harrington TJ, Faulder KC, Steinfort BS, Priglinger M, Ang T, Scroop R, Barber PA, McGuinness B, Wijeratne T, Phan TG, Chong W, Chandra RV, Bladin CF, Badve M, Rice H, de Villiers L, Ma H, Desmond PM, Donnan GA,
Davis SM; EXTEND-IA Investigators: Endovascular therapy for ischemic stroke with perfusion-imaging selection. N Engl J Med 2015; 372:1009-1018.

- 3 Jovin TG, Chamorro A, Cobo E, de Miquel MA, Molina CA, Rovira A, Román LS, Serena J, Abilleira S, Ribó M, Millán M, Urra X, Cardona P, López-Cancio E, Tomasello A, Castaño C, Blasco J, Aja L, Dorado L, Quesada $\mathrm{H}$, Rubiera M, Hernandez-Pérez M, Goyal M, Demchuk AM, von Kummer R, Gallofré M, Dávalos A; REVASCAT Trial Investigators: Thrombectomy within 8 hours after symptom onset in ischemic stroke. N Engl J Med 2015, Epub ahead of print.

4 Saver JL, Goyal M, Bonafe A, Diener HC, Levy EI, Pereira VM, Albers GW, Cognard C, Cohen DJ, Hacke W, Jansen O, Jovin TG, Mattle HP, Nogueira RG, Siddiqui AH, Yavagal DR, Baxter BW, Devlin TG, Lopes DK, Reddy VK, de Rochemont RD, Singer OC, Jahan R; SWIFT PRIME Investigators: Stent-retriever thrombectomy after intravenous t-PA vs. t-PA alone in stroke. N Engl J Med 2015, Epub ahead of print.
Berkhemer OA, Fransen PS, Beumer D, van den Berg LA, Lingsma HF, Yoo AJ, Schonewille WJ, Vos JA, Nederkoorn PJ, Wermer MJ, van Walderveen MA, Staals J, Hofmeijer $\mathrm{J}$, van Oostayen JA, Lycklama à Nijeholt GJ, Boiten J, Brouwer PA, Emmer BJ, de Bruijn SF, van Dijk LC, Kappelle LJ, Lo RH, van Dijk EJ, de Vries J, de Kort PL, van Rooij WJ, van den Berg JS, van Hasselt BA, Aerden LA, Dallinga RJ, Visser MC, Bot JC, Vroomen PC, Eshghi O, Schreuder TH, Heijboer RJ, Keizer K, Tielbeek AV, den Hertog HM, Gerrits DG, van den Berg-Vos RM, Karas GB, Steyerberg EW, Flach HZ, Marquering HA, Sprengers ME, Jenniskens SF, Beenen LF, van den Berg R, Koudstaal PJ, van Zwam WH, Roos YB, van der Lugt $A$, van Oostenbrugge RJ, Majoie CB, Dippel DW; MR CLEAN Investigators: A randomized trial of intraarterial treatment for acute ischemic stroke. N Engl J Med 2015; 372:11-20. Erratum in N Engl J Med 2015; 372:394.

6 Prabhakaran S, Ruff I, Bernstein RA: Acute stroke intervention: a systematic review. JAMA 2015;313:1451-1462. 